\title{
National Subjects, Citizens and Refugees: Thoughts on the Politics of Survival, Violence and Mourning following the Sewol Ferry Disaster in South Korea
}

Cho (Han) Haejoang

\section{Introduction: One Incident That Made People Ask 'What is a State?'}

Don't politics exist so that the people and the state do not engage in a naked clash for power? Don't politics lead two opposing parties, who would otherwise have no place to meet, to a common ground? Those currently in power, however, seem to have risen to their positions because of their lack of empathy and compassion. To avoid responsibility and climb even higher upon the rungs of power, they appear ready to step on more bodies... The most important thing, therefore, is the recovery of the political. However, this notion of political does not involve begging the state for power but making a public for ourselves. (Lee Gye-sam, social activist $)^{1}$

1 Lee Gye-sam, 'Chamsi mŏmch'wŏsŏja' [Let's Stop for a Moment and Stand Up], Hankyoreh Newspaper, 8 May 2014. 
Though I am not a particularly accomplished storyteller, I wish to share with you a story about a particular incident 事件, not accident 事故, that of the Sewol ferry in South Korea. ${ }^{2}$ Since South Korea's founding as a nation in 1948, many incidents-both large and small-have occurred on the Korean peninsula. However, this incident, which took place in 2014, was special in prompting many of its citizens to ask, 'What is a state?' This incident has forced many intellectuals and grassroots activists to contemplate more deeply about society, nation and the future of humankind. Furthermore, it has compelled many 'ordinary' citizens to seriously address the issue of 'survival politics'. It also compelled many young people to ponder whether they should continue supporting this state or shift their allegiance to another one, by emigration for instance. This incident has not ended but is still unfolding.

After the devastating civil war of 1950-53, South Korea transformed itself into the world's 13th-largest economic power in the short period of 60 years. Though Koreans often pride themselves on this fact, with the Sewol Ferry Disaster they seem to realise that there is something they could have done better. They have come to realise not only that South Korea is a highly risky society, but also that their 'loving nation state' has been feeding the avaricious market, while caring little about its people. Observing the collapse of Korean society after the Asian financial crisis in 1997, I wrote an essay arguing that there are 'no citizens but only a national subjects' and 'no individuals but only families'. ${ }^{3}$ The subjects that I found during the financial crisis and the ensuing recovery process were not the 'individual citizens (simin 市民)' but the 'national subjects (kukmin 國民)'. Rather than opening up a public/civilian space to discuss, reflect upon and resolve the crisis, the national subjects were desperately trying to overcome the crisis within the paradigm of the developmental authoritarian state. Moreover, they were doing so only as members of a family, not as individual citizens. There were few debates about the

2 There is an ongoing struggle between those who wish to view the Sewol tragedy as an unfortunate 'accident 事故' and those who wish to view it as a socially noteworthy historical 'incident 事件'. In a segment of the online forum of 'Slow News', started by some youth on 28 April 2014, they ask, 'Was Sewol tragedy an accident? Or an incident?' Warning against the irresponsible behaviour of the existing media outlets that have forsaken their duty of delivering accurate information, they declare that the Sewol tragedy was an 'incident' that has resulted from the 'overall failure of the system' within South Korea created by gross negligence. At the same time, they warn against the totalising perspectives implied by the term 'overall failure of the system', and, instead, emphasise the particular perspectives on this incident. plus.google.com/101120182737860073943/posts/c1QwKkc9riN.

3 Haejoang Cho, 'You are Entrapped in an Imaginary Well: The Formation of Subjectivity Within Compressed Development - a Feminist Critique of Modernity and Korean Culture', Inter-Asia Cultural Studies 1 (2000): 49-69. 
widening social divisions within society or about changing the direction of modernisation. Around 1997, however, there was still a certain amount of trust and loyalty in the state and family. Now, it seems difficult to find these. In an Organisation for Economic Co-operation and Development (OECD) survey, only 24.8 per cent of Koreans stated that they trusted the government. The average for OECD countries was 42.8 per cent, while 82.2 per cent of the Swiss said they trusted the government. Moreover, with the rapid disintegration of families, growing class polarisation, rising youth unemployment, and skyrocketing elderly poverty and suicide, South Korea seems one of the most wretched among the OECD states. If anything, the Sewol Ferry Disaster seems to have crushed any remaining faith in the state. As articulated by activist Lee Gye-Sam above, it has resulted in a standoff between the state and the people. How can people recover trust in their nation when all sense of public sentiment and politics seems irretrievably lost, or replaced by acrimonious cynicism? Dwelling on this question, South Korean people/citizens have been undergoing a profound experience of learning through the agony and anxiety produced by the Sewol Ferry Disaster. Rather than lamenting this seemingly hopeless situation, I view it as a time and space for selfreflection where people can fundamentally retool their consciousness. That is, I believe that catastrophic events, in providing a profound sense of 'social catharsis', can transform into 'emancipatory catastrophism'. ${ }^{4}$ As a Korean citizen and resident, who has, for the past two years, experienced the grief and depression of emancipatory catastrophism, I want to share some thoughts on modernity, violence and survival politics, and introduce terms such as 'citizens of compassion' and 'cosmopolitan refugees'.

\section{The Events Near Jindo Island, 16 April 2014}

After crossing the line of unimaginable pain, P'aengmok Harbor has become a mortuary of corpses. When the bodies arrive from the shipwreck, an hour and ten minutes away, the medical examiners call them out one by one using not names but rather only numbers and other details - 'Female \# 75, 168 centimeters, white short-sleeve shirt, black Adidas track pants, thin build, long hair, braces, birthmark on the right

4 Ulrich Beck, 'Haebangjŏk p'akuk: kŭgŏsŭn kihubyŏnhwa mit wihŏmsahoee ŏttŏhan ŭimiga itnŭnka?' [Emancipatory Catastrophism: What Does it Mean to Climate Change and Risk Society?], paper presented at The Seoul Conference 2014 with Professor Ulrich Beck Public Lecture. Organised by Joongmin Foundation for Social Theory, Center for Social Sciences of Seoul National University, 8 July 2014. 
side of face.' When some parents, who, upon hearing these words, cry out, 'Oh, that's my child!' and run off to identify the child, everybody cries. Parents who are waiting for the corpse of their child, congratulate those who have recovered theirs. Parents, who have recovered their child's body, feel sorry because other parents are still waiting to recover their own. As you can see, it's an unimaginable scene of pain and suffering with parents who have recovered their dead child, parents who are still waiting for their missing children, and volunteers who are helping both groups of parents. (Ju Jin-u, from Green Review) ${ }^{5}$

The 'Sewol Ferry Accident' or 'Disaster' occurred at 8:48 am on 16 April 2014 when the Sewol, a passenger ferry carrying 476 passengers and cargo, capsized off South Korea's southern coast near Jindo County. Initially, in the breaking news of the accident, all passengers were reported to be alive and to have been rescued. After these initial reports were quickly discounted, the country sat down to seemingly endless hours of live coverage of the ferry slowly sinking to the bottom of the cold spring ocean. Passengers on this ferry were mostly students from Danwon High School in Ansan, Kyung-gi Province, on a long-awaited field trip. Of the 325 students in total, only 75 of them survived the accident. ${ }^{6}$ Among the 15 teachers in charge, three survived. Two days later, one of the three surviving teachers, the head teacher-overcome with grief and guilt - hanged himself from a pine tree. As for the surviving families, they forged strong bonds of sorrow and grief as they shared scenes like the one described above at P'aengmok Harbor.

Amidst the sorrow and grief, there was hot, molten anger-anger on the part of surviving families who heard that the passengers on the illfated ferry were told, in an onboard announcement, to put on their life jackets and sit tight in their cabins until further notice. While the children who disobeyed the crew's instructions and came immediately onto the deck after the accident survived, those who obediently followed the announcement perished. Also enraging the surviving families and the public was the fact that the captain and ferry crew abandoned their youthful passengers and were the first to board the rescue boats. Finally, there was the irresponsible attitude of the president and her high-

5 Kim Jong-chul, Kim Young-ok, Ju Jin-woo, and Ha Seung-woo, 'Roundtable Discussion: Hangukiranŭn nara, hŭimang ŭn itnŭnga?' [Is There Hope Within a Country like South Korea?], Noksaek Pyungrone [Green Review] 137 (2014): 41-2.

6 Lee Young-ji, “'Sewŏlho ap'ŭm” tanwŏn'go chorŏbsik... saengjonhaksaeng do chorŏpsaeng do urŏtta' ['The Pain of Sewol' and the Graduation Ceremony at Danwon High School: Even the Surviving Students Cried], Yonhap News, 9 January 2015. 
ranking officials when they visited the accident site. Rather than lamenting the untimely deaths and worrying about the state of grief of other people in the country, they appeared to be more concerned about avoiding public blame. According to reporter Ju Jin-u, with the government doing little to defuse public anger and alleviate suffering, it was mostly bystanders and volunteers who carried the torch of hope for the grieving families. ${ }^{7}$

At the same time, mysteries involving mind-boggling acts of ineptitude remain unresolved. On that morning, when the youthful passengers were texting their families for help or to say goodbye, the Korean Coast Guard sent out no rescue boats. Soon after the accident, the public also learned that Sewol had been a decrepit ferry with an extended lifespan. The ferry Sewol (meaning to 'transcend the world' in Korean) had been owned by a 73-year-old CEO named Yoo Byung-un, who was later discovered to be the leader of Kuwon-p'a, a religious sect awaiting the millennium. Like many successful business leaders, he had built his company through corrupt relations with politicians. For instance, due to the deregulation of the shipping industry by the previous Lee Myung Bak administration, Mr Yoo was able to import an 18-year-old ship from Japan in 2012 and modify it in order to add more room for passengers and cargo. He managed to carry out these modifications despite their violation of various safety regulations. The public also became incensed when they learned about the short-term contract for the captain, indicative perhaps of his level of experience or reliability, and lack of safety training for the crew. Still, it was not until they learned about the missing CCTV tapes and internal communication records that they began to ask a more fundamental question: 'Where was the state, responsible for the safety of its people, during all this?' Prior to the accident, many had prided themselves on being members of an advanced nation. Adding to their frustration was the lack of information, which gave rise to wild rumours and deepened the public's sense of misgiving and distrust of the government. While the government remained tight-lipped about the accident, the mainstream media focused its attention on an extensive manhunt for $\mathrm{Mr}$ Yoo, who had gone into hiding. The country's mood became further agitated when a body was discovered in a village garlic field on 12 July, giving rise to wild rumours on the internet that it was Mr Yoo's.

7 Kim Jong-chul et al., 'Roundtable Discussion', 8-9. 
Earlier, on 19 May-several weeks after the prime minister took the blame for the accident and resigned-President Park Geun-hye took to the podium to address the nation. As she wiped away tears and called out the names of the adult passengers who had died on the ferry while trying to rescue other passengers, she said she took full responsibility. Then, addressing the widespread rumours of collusion between the government and private sector, she announced the dismantling of the Korean Coast Guard and the establishment of the Ministry of National Safety in its place. Through such reforms, she vowed to dig out the poisonous roots of Kwan-p'ia (Bureaucratic Mafia) that had 'held the lives of the nation for ransom' ${ }^{8}$ Finally, she proposed setting up a Truth Commission to investigate the causes of the accident and the failure of the rescue effort. Rather than reassuring the surviving families and public, however, the president's address further aggravated them. Many wondered whether the dismantling of the Korean Coast Guard would bring those responsible for the botched rescue effort to justice or let them off scot-free. Instead of investigating the many questions that the public had about the accident, the prosecutors also focused their energy on guaranteeing the death penalty for the ferry captain, as if that would solve all the mysteries surrounding this accident. Finally, in order to demand a thorough investigation of the accident-i.e. what had happened, how it happened, and how tragedies like this could be prevented in the future-the surviving families began a vigil in Seoul's downtown plaza.

In the aftermath of the accident, the surviving families lived like refugees, sleeping on the floors of makeshift accommodations within gyms, tents, and funeral homes near the site where the ferry sank. As they shared grievances and tried to make sense of this senseless tragedy, the parents of the students at Danwon High School bonded like no other victims of any tragedies before. ${ }^{9}$ Together, they engaged in various protests and marches to make sure that a similar accident would not reoccur within Korean society. In one protest, they marched to the headquarters of the Korean Broadcasting System (KBS), a public corporation that had been heavily criticised for its highly distorted accounts of the disaster. After that, they marched to the Blue House, home of the Korean president, to demand the passage of a special law to guarantee the political neutrality of the Truth Commission proposed by President Park. However, not only

8 article.joins.com/news/blognews/article.asp?listid=13414472.

9 Refer to the early CNN news coverage. www.youtube.com/watch?v=4i_qKM7SMn8

24 April 2014. 
did the president refuse to meet the families, KBS's biased coverage of the disaster continued, prompting the families to carry out another protest on 14 May calling for the resignation of its CEO Gil Hwan-young. While KBS reporters at the site of their protest shed tears of sorrow, the KBS editorial office refused to allow coverage of the demonstration..$^{10}$ Moreover, while KBS's CEO did eventually resign, he was quickly replaced by another CEO who shared a similar background and views.

After camping for 76 days outside the Blue House, the families moved their protest to Kwanghwamun Square-a large open area that sits amidst tall government buildings in the administrative core of Seoul. Overnight, these families, who had been living ordinary lives as middle-class people waiting for their children to grow up, attend college, and pursue their dreams, became activists as they began to lose their previously held trust in the government. Vowing to avenge their children's deaths and prevent a similar accident in the future, they approached Min-pyón (Lawyers for a Democratic Society) to ask for their help in launching a Special Investigation Committee. The aim of this committee was to pressure the government to set up a Truth Commission as soon as possible and pass a special law to grant it strong investigatory and prosecutorial powers. In order to ensure the political neutrality of this commission, they also proposed that half of its members be composed of individuals nominated by the government and the other half of individuals nominated by the committee. Throughout the entire process, the surviving families and the Special Investigation Committee tried to maintain a neutral position visà-vis the government and utilise official channels. Neither proved to be an easy task as society was already too polarised and corrupt.

Along with an ultra-right wing group of conservative nationalist Christian organisations, some radical right-wing young people soon emerged to express their open hostility towards the surviving families and their street protests. These conservative groups began to put forth a counter-discourse, accusing the families of making 'unreasonable' and 'excessive' demands on the government that sowed social disorder and contributed to economic stagnation. After exhaustively covering their

10 “"Chega kachog iŏdo...” KBS kicha ŭi nunmul' [Even if I'm a Family Member, the Tears of a KBS Reporter], YouTube video, 0:22, posted by 'Newstapa', 5 May 2014. www.youtube.com/ watch?v=iFzK2hjpbms. 
activities, the mainstream media began to pressure the families to just 'let things be'. Deploying the expression 'public fatigue', it began to assert that people were tired of hearing about the families' protests.

According to Han Wan-sang, a respected academic and intellectual, this type of discourse that employs expressions referring to 'public fatigue' can be considered a form of linguistic censorship, comparable to Nazi propaganda employed during the totalitarian period. ${ }^{11}$ Indeed, quotations from master Nazi propagandist Joseph Goebbels, such as the following, could be easily found circulating on the internet:

It would not be impossible to make people believe that a square is in fact a circle with sufficient repetition and a psychological appeal. They are mere words, and words can be molded until they clothe ideas and disguise ... One cannot determine theoretically whether one propaganda is better than another. Rather, good propaganda has the desired results and bad propaganda does not lead to the desired results. It does not matter how clever it is, for the task of propaganda is not to be clever, its task is to lead to success. ${ }^{12}$

While grieving continues to occur in Ansan, where the students had gone to school, similar protests and vigils have spread among diasporic Koreans, especially mothers, in cities around the world. ${ }^{13}$ This essay, however, will focus less on these social activities of grieving and healing than on the discourses that have emerged and surround this disaster. In prompting many people to question the state's ability to safeguard the safety of its people, the Sewol Ferry Disaster has become a key political issue that has rent the nation in two. While one group claims that the country can only move on from this disaster after properly mourning the deaths of these children, the other claims that it was a simple 'accident'. They condemn the surviving families and their supporters for 'pestering' the government. In the next section, let us examine the positions of these polarised groups more carefully.

11 Han Wan-sang, 'P'iro tamron' p'ŏttŭrinŭn i ttang ŭi 'sŏnjangdŭl' [The 'Captains' of this Land who are Propagating the 'Fatigue Thesis], Hankyoreh Newspaper, 11 September 2014.

12 Kim Jae-han, 'Sŏndong en chŭngo ŭi taesang p'ilsu ... koepelsŭ, chŏnsŏn nŏmu hwagdaehae chamyŏl' [Instigation Necessitates the Target of Hatred ... Goebbels's Aggrandising of the Enemy Line led to Self-Destruction], Joong-ang Daily, 25 April 2014.

13 For example, there is a Sewol Ferry Disaster protest as part of a peace rally held every Wednesday in Minneapolis, US, and there is a Remembering Sewol UK team (rememberingsewoluk.wordpress. com) that holds candlelight rallies, makes social media postings, organises study groups, etc. 


\section{Grieving Citizens and the Politics of Compassion}

It's not as if we heard about the Sewol Ferry Disaster afterwards. Rather, it was like we were there with the students on the ferry as it slowly sank into the sea. With images of the ferry accident transmitted to us in real time through the media, the whole country saw its sinking last April. So it wasn't something that we 'heard' or 'read about' afterwards but something that we 'saw' directly with our eyes as we sat or stood where we were in our everyday lives. Day-by-day, achingly slowly, we saw it unfold on the morning news, the evening news, and on the Internet. While people responsible for the disaster were busy calculating their losses and avoiding blame, we saw the ferry sink further into the sea. Eating, sleeping, working, walking, we saw it. And even now we continue seeing it and it is likely we will be made to continue to see it whether the ferry breaks up, rusts away, or becomes metal in a scrap yard. (Kim Ae-ran, excerpt from 'Slanted Spring, What We Have Seen') ${ }^{14}$

Observing the unfolding Sewol Ferry Disaster and its grief-stricken families, the entire nation was given an important opportunity to reflect on their lives. Viewing this disaster as an important window into Korean society, Jeon Gyu-chan, a media scholar, called it a 'remote visual event'an event that unfolded before the eyes of the nation like 'a horrible nightmare with nothing to veil it'. ${ }^{15}$ During its unfolding, the mainstream media - operating under strict government censorship-earned the title of $k i-r e-k i$ (journalist garbage) for its highly distorted coverage. Even so, through its 'outstanding affective and intellectual perception', the viewing public, Jeon Gyu-chan argues, was able to grasp the essence of the situation with just a passing glance. Perhaps realising that they too live in an era overshadowed by death, the viewers formed a 'grieving community' in front of their television screens. Psychotherapist Carl Jung argued that when a community experiences a tragedy, it becomes afflicted by a 'big dream' that serves as a collective warning. Certainly, the Sewol Ferry Disaster was one such event in South Korea, making everyone aware of the fragility of their everyday lives within which a tragedy like this could befall anyone at any time.

14 Kim Ae-ran, 'Kiunŭn pom, uriga pon kŏt' [Slanted Spring, What We Have Seen], in Kim Ae-ran et al., Nunmŏn chadŭl ŭi kukka sewŏlhorŭl paraponŭn chakkaŭi nun [A Country Gone Blind: Writers' Perspectives on the Sewol Ferry Accident] (Paju: Munhak Dong-nae, 2014), 12.

15 Jeon Gyu-chan, 'Yŏngwŏnhan chaenansangt'ae: Sewŏlbo ihuǔi sikanǔn ŏpta' [Perpetual Calamity: There is No Time After Sewol], Kim Ae-ran et al., Nunmŏn chadŭl ŭi kukka, 154-5. 
As people converged around the surviving families' protests, many others around the country refrained from drinking, singing and dancing, and set up similar altars for grieving. Every night, groups of citizens-mothers of young children, in particular-held candlelight vigils in their respective neighbourhoods with banners that read 'We Will Never Forget', 'Let Us Fly to Where There is No More Corruption, Calculation and Conspiracy!' and 'Once a Happy Family, We Have Lost Everything'. During this national grieving, Lee Chul-soo, a print artist and a highly respected public intellectual, engaged in an artistic performance of sending online postcards to his fans, mourning the children's deaths. Here is his first postcard, postmarked 16 April:

There were too many-too many and too young. Some agonies, growing pains, and many dreams. Some just starting their first love, some trying to make their dreams come true. Meeting only death in that southern sea, you are now lost. What was that moment like when you were drawn to your death? So many people wailing in despair for you. If your death weighs so heavily upon our hearts, how unbearable it must be for your families. The possibility of a miracle to save you hanging by a single thread as the dark night descends. We can't even find words to offer our condolences.

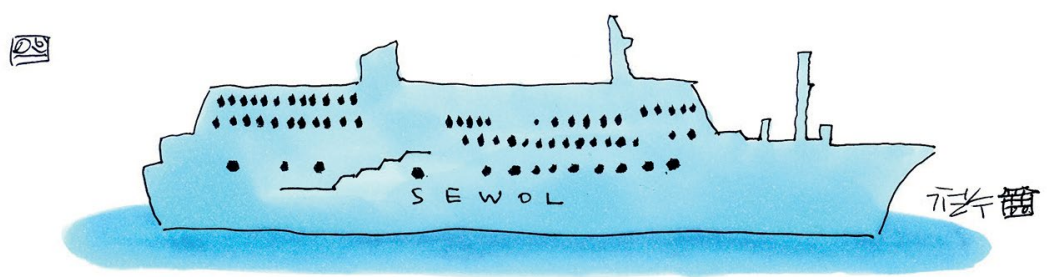

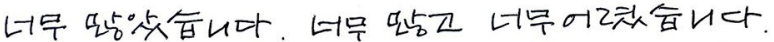

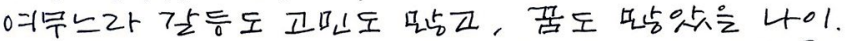

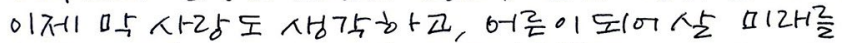

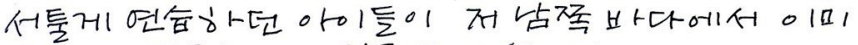

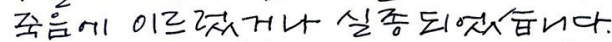

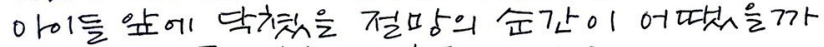

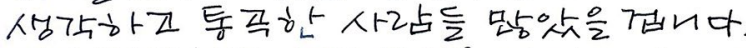

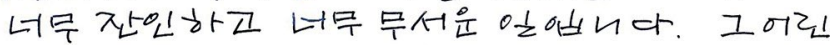

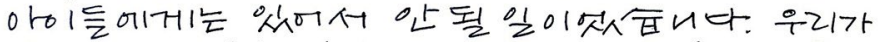

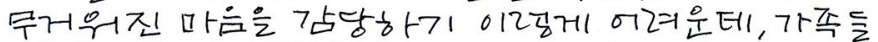

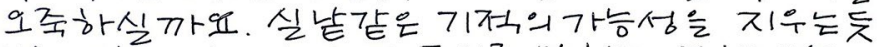

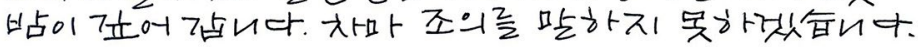

Figure 6: 'Too Many. Too Many and Too Young.'

Source: Courtesy of Lee Chul-soo. 
On 25 April, he sent another postcard with the following inscription, 'Fly from the Depths of the Sea to the Heavens!'

The world is weeping. Farewell. Farewell. To a land without collusion, without endless calculations of profit, without bribery. To such a place, go, you beautiful souls. There is no such place here. There is no such place here.
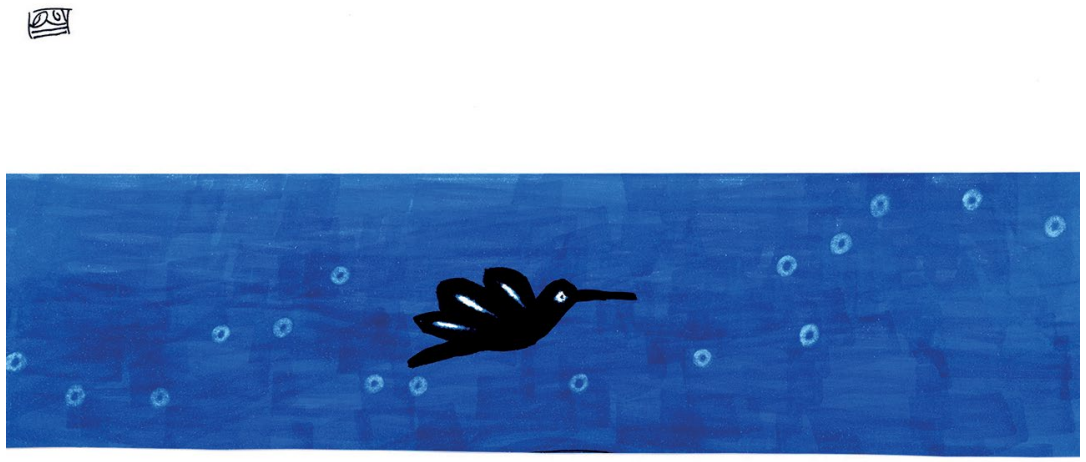

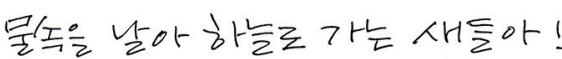

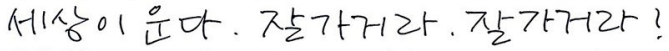

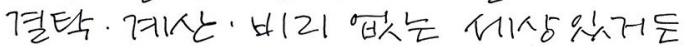

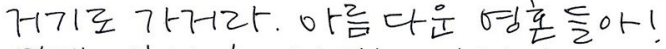

$$
\begin{aligned}
& 0171 \text { 结 othat. } 0171 \text { t }
\end{aligned}
$$

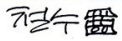

Figure 7: 'Farewell. Farewell.'

Source: Courtesy of Lee Chul-soo.

On 5 May, he wrote still another postcard with the following quote from one of the surviving families:

We were poor but happy. But, now that you have gone, we are completely destitute.

With the establishment of the Task Force for the Families of Victims/ Missing/Survivors and the Citizens Task Force for Sewol Ferry Disaster, the 10-million signature petition for the passage of Sewol Special Law began. By 7 June 2014, the petition had collected one million signatures. By the first-year anniversary of the disaster, that number had ballooned to six million. ${ }^{16}$ On 8 July, two bereaved fathers also began a 750 -kilometre

16 Jang Sul-gi, “"600-man sŏmyŏng muryŏkhwahanŭn sihaengryŏng”, kilkŏri nongsŏng sichak' ['The Ordinance Neutralising the Power of 6-Million People Petition', The Start of the Sit-Down Protest], Media Today, 30 March 2015. 
trek across the country from Danwon High School to Paeng-mok Harbor carrying a cross. During this long trek of mourning, tens and hundreds of citizens, who wished to share their grief and consolation, greeted them. On 14 July, urging the adoption of a proper Sewol Special Law, the Sewol Ferry Disaster families began fasting. This drew people who wanted to show their solidarity not only to Kwanghwamun Plaza, but also onto online spaces, where individuals posted pictures and shared stories of their own fasting. On YouTube, people began to upload videos of Sewol commemorations, such as fields of yellow ribbons to express people's grief. Nationwide, citizens held protests with banners that read 'Life before profit!' and 'People before money!', as well as open forum discussions, which prompted many to reflect on their fast-paced lifestyles and question the cherished concepts of 'nation', 'compressed modernity', and 'unbridled neoliberalism'. Soon, these acts of grieving took on more artistic and cultural forms. While the Hankyoreh Newspaper printed stories and sketches of children who had passed away by cartoonist Bak Jae-dong, an art gallery exhibited the keepsakes of a girl who had dreamt of becoming a fashion designer before dying in such an untimely manner.

On the 100th day after the sinking, various commemorations took place nationwide, including a concert by the Paris-based and world famous pianist Paik Kunwoo. After cancelling a world tour, he held a concert on Jeju Island (the destination of the ill-fated ferry) instead, to mourn the children's deaths. In front of Seoul Plaza at City Hall, over 50,000 grieving citizens gathered under the slogan 'A Day of Promise to Never Forget'. On the stage, Kim Jang-hoon, a popular activist singer, sang a duet with the recorded voice of a girl who had died on the ferry but left behind an audition tape, bringing the audience to tears. At the end of the concert and memorial service, everyone applauded when popular singer, Lee Seung-hwan said, 'I suddenly realize that we are such pitiful people with a state that is either unable or unwilling to protect its people. Instead of avoiding this ugly truth, however, let us eat well and stay strong so that we may never forget what we have seen and learnt from this tragedy. ${ }^{17}$

17 '[NocutView] 'Kimchanghun- Yisŭnghwan, nunmul ŭi k'onsŏt'ŭ “4.16 chŏltae itchi ankesssŭmnida”' [Kim Jang-hoon \& Lee Seung-hwan, the Concert of Tears, "We Will Never Forget 04/16], YouTube video, 3:03, posted by 'NocutV', 25 July 2014. www.youtube.com/watch?v=1HER muciE0s\&feature=youtu.be. 
Overseeing this act of mourning were over 10,000 police and military troops as part of 130 squadrons that were deployed to control the grieving public. $^{18}$

In addition to these spontaneous acts of civic gathering, a flood of writings began to appear on the disaster. Declaring that the Sewol Ferry Disaster was 'not an omen but the result of accumulated events', novelist Bae Myung-hoon writes: 'Though there have been many warnings, the strange and unsavory ways in which the nation state has been operating have been made crystal clear by this accident'. ${ }^{19}$ Viewing the Sewol Ferry Disaster as more than an 'accident', rather a momentous 'event' that has unveiled the state's corrupt inability to protect its own citizens, novelist Pak Mingyu wrote a highly metaphorical account of 'The Sinking Ferry of South Korea', likening the nation to the doomed Sewol, a vessel that was built and originally operated in Japan, and then ineptly refitted to enable it to carry a dangerously large load. Analogously, Pak depicts Korea's system as being shaped by Japanese colonialism, dangerously 'retrofitted' under postwar US auspices, and then operated by a crew of politicians and citizens who failed to acknowledge that their ship was sinking.

Looking back, 10 years was too short a time to build a democratic nation, which had a distorted concept of 'public interest' from the beginning. Since the colonial period, the most ardent desire of Korean people has been to become the confident and dignified members of an independent nation. Unlike citizens in the West, who had built their cities and publics since the 12th century, Koreans became 'colonial' citizens of a modern nation only in the 19th century. Identifying the public with the state, they became readily mobilised by the state during its modernisation process. During this process, they continued to view the public as a state-dominated community rather than a voluntary community of communicative citizens. This perception of the public also appears within the language. The terms, 'people' and 'citizen', have very different connotations. To be more precise, 'people' referred to 'national subjects', a collective body of mobilised people rather than 'citizens', who can make and change the nation from below. Through the Sewol Ferry Disaster, Korean public intellectuals have realised the folly of identifying the public

18 Im Jong-myung and Kim Yae-jee, 'Sewŏlho 1chugi sŏulkwangchang 5manyŏ unchip... ch 'umoche mach 'igo haengchin' [50,000 Citizens Who Have Gathered for the 1st Anniversary of Sewol Diaster in Seoul Plaze Commemorating That Day], NEWSIS, 16 April 2015.

19 Bae Myung-hoon, 'Nuka tapeya halkka?' [Who Should Answer?], Kim Ae-ran et al., Nunmŏn chadŭl üi kukka, 105-6. 
with the state. For instance, some people have responded to the demand of the surviving families 'to investigate and prosecute those responsible for the accident' with the statement that it is like 'handing a knife to the victim of a crime'. In reply, Pak Min-gyu retorted, 'Does that mean that we should give the knife back to the killer instead?' In a nation dominated by the state, he asks, 'Who should stand as the judge of the public when the state is a criminal suspect and the public enemy is the public itself?' ${ }^{20}$ Following the accident, protestors have cited Article 1, Clause 2 of the Constitution most frequently within their protests: 'the sovereignty of the Republic of Korea shall reside in the people, and all state authority shall emanate from the people'. This chapter, once again, expresses the strong will of protestors to recover the 'state for the people'.

The Sewol Ferry Disaster has dredged up acute feelings of sadness and anger within the Korean people. ${ }^{21}$ If, as cultural critic Kim Young-ok argues, politics is the transformation of everyday feelings, emotions and consciousness into public speech, then this disaster has done exactly that. It has forced people to take the small moments of self-awareness that have formed from gazing into the black hole of despair and transform them into public speech. Shuttling back and forth between the public and private spheres, the surviving families and mourning citizens are recovering the practices of empathy and mourning that were either suppressed or excluded from the phallocentric political sphere. One such ritual drew upon shamanistic and Catholic practices. Upon hearing that the parents' hearts were heaviest when they were sorting through the box of possessions of their deceased child recovered from the accident, a group of nuns set out to alleviate the sorrow of one mother who had lost her son in the Sewol Ferry Disaster. As the mother took her son's clothes out of the box and into the bathroom to wash them one by one, the nuns sat on the floor lit with a candle and sang hymns. As the mother dried, ironed, and folded the clothes, other mourners recited poet Chun Sang-byung's Kui-ch'un ('Returning to Heaven') and wailed in grief. The mother thus bid farewell to her child with utmost love and devotion. Although few parents could partake in this kind of mourning ritual attended to by the nuns, various other forms of mourning and healing have taken place in Ansan. Though I do not cover these rituals of mourning extensively within this essay, I wish to emphasise the ways in which the Sewol Ferry Disaster

20 See Kim et al., Nunmŏn chadŭl ŭi kukka, 53.

21 Kim Jong-chul et al., 'Roundtable Discussion', 6. 
has given rise to these collective practices of grieving that allow people to recover their sense of mutual dependency and ethical responsibility. ${ }^{22}$ Also providing great condolence was Pope Francis's visit to South Korea from 13-18 August, ${ }^{23}$ which prompted many people to begin asking how they could share another's pain.

Following the public outpouring of grief and protests, intellectuals and social scientists went on to develop further discourses about the relationship between the Korean state and neoliberalism, arguing that this disaster represented not a glitch but a basic flaw within the entire system. Scholars ranging from economist Woo Sun-wook ${ }^{24}$ to sociologist Han Byung-chul claimed that the real culprit behind the children's murder was not the ferry captain or its owner but neoliberalism. They claimed that the Sewol Ferry Disaster was the natural culmination of 50 years of compressed modernisation during which the pursuit of economic growth became privileged above everything else. Scholarly publications, including those by Jin Jang-duk, argued that this tragedy disclosed the 'dual nature' of South Korea's risk society: its structural deficiency in terms of the shipping industry and the broader problems of Korean society caught in the tidal wave of privatisation. ${ }^{25}$ Historian Park Myung-rim has brought up the issue of modernisation without social welfare by pointing out how Western countries became neoliberalised only after having enjoyed a social welfare state for many decades. In contrast, South Korea, in adopting neoliberal ideals almost immediately after the overthrow of military dictatorships, continues to have weak social welfare programs and is experiencing what he terms 'malicious neoliberalism'. ${ }^{26}$

22 'Many people think that grief is privatizing, that it returns us to a solitary situation and is in that sense, depoliticizing. But I think it furnishes a sense of political community of a complex order, and it does this first of all by bringing to the fore the relational ties that have implications for theorizing fundamental dependency and ethical responsibility.' Judith Butler, Precarious Life: The Powers of Mourning and Violence (Verso, 2004), 22.

23 'P'ŭranch'isŭk'o kyohwang, sewŏlho danshik 34-il Gim yŏng o-ssi wiro' [Pope Francis Comforting Kim Young-oh's 34-day Sewol Disaster Fasting] YouTube video, 1:21, posted by 'MediaVOP', 15 August 2014. www.youtube.com/watch?v=A-81bkiuQYk.

24 Woo Suk-hoon, Naeril su ŏmnŭn pae [A Boat That One Cannot Get Off] (Paju: Oong-jin Jishik House, 2014).

25 Chang Duk-jin et al., Sewŏlhoga urieke mutta chaenangwa konggongsŏng ŭi sahoehak [Sewol Disaster Asks Us: Sociology of Disasters and Publicness] (Paju: Han-ool, 2015).

26 Lee Sae-young, 'Saramŭi kach'irŭl chik'iryŏ...tasi konggongsŏngida' [People are the Centre. A Country with a Collapsing Public: What Caused the Sewol Ferry Accident?], Hankyoreh Newspaper, 14 May 2014. 
These academic discourses, however, fail to sway ordinary citizens who grieve. Part of the reason for this gap between academic discourses and popular sentiment is the control of media and information by the state power. Another reason is the highly judgemental language used by intellectuals as well as ordinary citizens. The intellectuals, as members of the post-Enlightenment generation, pretend that they know the truth. The tone of their discourse closes down-rather than opening up-a dialogue. As discussions of the Sewol Ferry Disaster continued to be framed through the discourses of nationalism and familism, the majority of citizens, who initially felt the 'heart of heaven' descend upon them, find themselves increasingly estranged from the protests. I consider this unfortunate trend to be the result of South Korea's modernisation process, which has paid little attention to the formation of a public sphere where citizens could voluntarily meet and solve their collective problems. Now there are people with hatred in their hearts who protest against the opening of the public sphere of grieving. In the next section, let us examine these growing voices of opposition.

\section{National Subjects of Animosity and the Politics of Fear}

The political climate after the Sewol Ferry Disaster has become infinitely more complicated. Observing the unfolding events of the Sewol Ferry Disaster, social critic Gang June-man, from the perspective of a progressive and concerned citizen, has identified five stages of despair. ${ }^{27}$ The first was realising that none of the involved parties - the ferry owner, captain, or crew-considered life more important than money. The second was witnessing the disappointing attitudes and responses of public authorities, including the maritime police. The third was seeing the president and politicians reflect similarly irresponsible attitudes. The fourth was noting that not all shared the indignation of the grieving families and citizens. The fifth was tallying the results of the regional elections, which took place 49 days after the accident. Intellectuals had expected people to turn their backs on the conservative politicians, not one of whom had a sensible plan to ease the nation's sense of loss and hopelessness. Instead, the reelection of these same politicians shattered the intellectuals' own naive belief in the people. After this series of disappointments, the Sewol Ferry 
Disaster became stuck in the opposing logics of the two political parties. While the left-wing opposition party tried to use the issue to expand its own power, the right-wing government, tense at the possibility of being blamed for the disaster, tried to bury it altogether. When a certain segment of civil society joined the opposition party's call for the resignation of the president, the Sewol Ferry Disaster simply spawned more controversies.

Adding fuel to the fire have been the controversies around the Sewol Special Law. When the surviving families demanded a closer examination of this law, some netizens began to make sensationalist claims in order to oppose them. Among them were: 'The surviving families are demanding the designation of all victims as national martyrs'; 'Are Sewol families some kind of government?'; 'The efforts of the surviving families to extract one more cent from the government are now exposed'. Through this smear campaign, they tried to portray the families as selfish individuals out for personal gain. ${ }^{28}$ Even though these claims are groundless, they have become the primary way to understand the Sewol Ferry Disaster.

In fact, one of the growing problems within Korean society is the inability to distinguish fact from fiction, with struggles for truth giving rise to further falsehoods. These falsehoods are then further manipulated to exacerbate an already tense political situation. For instance, when one man, identifying himself as the descendant of a Korean War veteran, proposed the formation of a group to oppose the passage of the Sewol Special Law, he was soon joined by the ultra-right Fathers' Coalition. Not only did they make ridiculous claims about these surviving families demanding special privileges for their deceased children, they also compared the Sewol Ferry Disaster to an ordinary traffic accident that neither the state nor the nation was responsible for. In their words, the children had simply died on a school trip, which they undertook out of their own volition and for their own pleasure. When the parents of the Sewol victims began a hunger strike on 17 July to demand a fair and speedy investigation of the accident, anti-Communist and ultra-right wing groups, including the Fathers' Coalition and fundamentalist Christians, gathered to denounce them as bad parents. They also claimed that giving the surviving families the power to hold an independent and impartial investigation would shake the legal foundation of the country. Portraying the fasting parents

28 Lee Ju-young, 'Sewŏlho yugachok tulrŏssan ŭihok 3kachi, chinsil ŭn?' [Three Doubts Surrounding Sewol Disaster's Surviving Families: The Truth?], Ohmynews, 16 July 2014. 
as a pro-Communist and pro-North Korean force bent on toppling the government, some even warned the president of a second Kwangju Uprising. ${ }^{29}$

At the hunger strike, joining the Fathers' Coalition were the 'Volunteer Battalion of Mothers' - a team of middle-aged women in vests who carried picket signs with incendiary messages on them, such as 'How much financial compensation do you want, that you are out here fasting and protesting instead of quietly crying at home?' or 'How well do you want to live that you're willing to sell [the bodies of] your children?' As groups like these waved these signs in front of the fasting parents, ${ }^{30}$ wild rumours began to spread widely, especially among senior citizens. Among them were accusations that the surviving families were putting forth political demands only to wrestle more compensation from the government. Taxi drivers and shopkeepers often asked me whether the protests of the families were not prolonging the economic recession. Others stated that the state should not compensate these families since their children had died in a 'boating accident' and taxpayers had not agreed to use their taxes to compensate them. In 2015, when the amount of the families' compensation was finally determined, an old lady in my neighbourhood asked me, 'I heard that if a person gets hit by a car, he receives US $\$ 200,000$ (200 million won) in compensation. Why is it then that the surviving families are getting US $\$ 800,000$ (800 million won)?' She then added, 'I heard that the costs of recovering the sunken ferry are astronomical. So why bother trying to recover it at all?' When I asked her about the source of this information, she answered, 'Kakao Talk', which is a phone and messaging service similar to WhatsApp or Skype. In a mediascape of smart phones and internet shared by all generations, these distorted rumours spread quickly even among the older generation of grandparents in their 60s and 70s.

The group that concerns me most is that of young people who show strong animosity toward the surviving families. As one example of their obnoxious behaviour, on 6 September, in a so-called '100 Pizza Party' sponsored by a businessman, they sang, danced and gorged on food in

29 Yonhap News, 23 April 2014; The Kwangju Uprising, also known as Kwangju Democratisation Movement, was a popular movement crushed by government troops under Chun Doo-hwan in May 1980 in the city of Kwangju, South Cholla Province, killing more than 600 civilians.

30 Bak Bo-na, 'Anchŏnsahoenŭn ŏttŏhke kanŭnghanka? "Chasik p'ara hogangharyŏ hanya” nŭn pibang e tapanda' [How is a Safe Society Possible? Responding to Slanderous Accusations of 'Selling One's Children to Live Well'], Ohmynews, 29 July 2014. 
front of the fasting families outside their Kwanghwamun shelter. Further fomenting hatred have been the actions of 'Ilgan Best' (Ilbae), an online community originally known for their political satire, which is now promoting hatred against social minorities including women, people from Cholla Province (the home region of president Kim Dae Jung who fought against president Park Jung Hee's military regime, often a target of discrimination by people from other regions) and foreign migrant workers. ${ }^{31}$ Ilbae members, who consider social minorities to be free riders, say that they are fed up with helping them. They make spurious claims that '[i]f the Sewol Special Law gets passed, the surviving families will get too many benefits' and '[i]mpure forces are using the unfortunate deaths on Sewol ferry to siphon off national resources'. In such a manner, they express their concern for the country. ${ }^{32}$ Even a few years ago, this kind of behaviour was socially unacceptable. ${ }^{33}$ However, by widely reporting on these hateful protests, conservative news outlets not only condone them but also exploit them to try to turn public opinion against the surviving families' struggle for justice.

Another target of public attacks was a father, who, after losing his daughter, began a month-long fast to demand the passage of the Sewol Special Law. When the fact of his previous divorce became public knowledge, all types of smear campaigns began to surface. While some claimed that the father, Kim Young-oh, 'had not once changed a diaper in his life', others accused him of 'enjoying the high-class sport of archery even though he had never paid one cent in alimony'. In the face of media attacks that portrayed him as an unfit father because he was divorced, Kim Young-oh was forced to reveal a copy of his empty bank account. Within it were figures for the money that he had wired to his ex-wife for their daughter's living expenses, including health insurance and cell phone bills. ${ }^{34}$ According to sociologist

31 For Ilbae, refer to Kim Hak-june, The Emotional Fellowship of Hatred and Wildness in Internet Community's 'Ilbae Storage Site'. Master's thesis, Seoul National University, Sociology (2014); Yoon Bo-ra, 'Ilbae and Hatred Against Women', Jinbo Pyungrone, Issue 57 (2013): 33-56. Bak Seun-young, 'Wigi ŭi namsŏngdŭl "yŏsŏng ŭn paeryŏ anin ch'ǒkkyŏl taesang" twit'ŭllin chŏkkaesim' [Men in Crisis: Women as Objects not of Consideration but of Eradication: A Misdirected Hostility], Hankgook Ilbo, 30 May 2015.

32 'Wigi ŭi namsŏngdŭl “yŏsŏng ŭn paeryŏ anin ch'ŏkkyŏl taesang” twit' ŭllin chŏkkaesim' [Men in Crisis: Women are not Subjects of Care but Elimination], Hankook Ilbo, 26 May 2015.

33 Chae Gyung-june, Kim Si-yuen and Lee Hee-hoon, 'Ilbae, Sewolho tansiknongsŏngjang chupyŏnseo" "pizapati' kkaji”' [Ilbe: Even a 'Pizza Party' Near Sewol Disaster's Fasting Family Members], Ohmynews, 6 September 2014.

34 Lee Hyun-jeong, 'Ingansŏng, kachok, kŭriko kiŏkhanŭn haengwi e kwanhayŏ' [Humanity, Family, and the Practice of Remembering], in No Myung-woo et al. eds, P'aengmokhangesŏ pulŏonŭn parlam [The Wind Blowing from P'aengmok Harbor] (Hyunshil Munhwa, 2015), 113. 
Kim Dong-choon, President Park Geun-hye and her administration have used various tactics, including employing the Korean state intelligence agency, to spread vicious rumours and pit the surviving families against each other. These tactics, he argues, constitute a form of informational warfare aimed at protecting their power and authority. ${ }^{35}$

Like others, I remain highly critical of efforts by the Park Geun-Hye administration and mainstream media to discredit the surviving families and bury the truth of what had happened on the Sewol. I also consider it necessary to better understand those citizens who so readily believe their lies. Dwelling on a similar issue, Kim Dong-choon attributes the animosity of the older generation to their wretched lives. According to him, people in their 60s and above have a tremendous amount of anger and resentment that they are unable to express as legitimate grievances. Even though they consider themselves the main agents behind the country's rapid economic ascent under the military government, many continue to live impoverished lives. Therefore, having never asked for nor received any compensation from the state, they feel a severe sense of relative deprivation when they hear the surviving families demanding reparations. ${ }^{36}$ Moreover, to the 'Cold War' generation, the term 'redistribution' automatically evokes feelings of repulsion. They consider it selfish and corrupt to talk about compensation when reviving the stagnant economy remains such an urgent task. Therefore, they repeatedly assert that the Sewol Ferry Disaster was simply an accident that neither the state nor government is responsible for. They also declare that the bereaved should not do anything to promote social disorder and deepen the economic recession. Still, despite the animosity that these far right-leaning seniors share with their younger counterparts, their root of discontent does not lie in unbridled neoliberalism but the Cold War system.

Contrary to many people's perception of Ilbae as young fanatics, many are, in fact-according to sociologist Kim Hak-june, who has done extensive field research within this community—kind and polite young men with

35 Kim Dong-choon, 'Kukka puchaewa kamchŏngchŏngch'i: sewŏlho ch'amsa ihuŭi hankuksahoe' [The Absence of the State and Politics of Emotion: Korean Society after the Sewol Ferry Disaster], No et al., P'aengmokhangesŏ pulōonŭn parlam, 188.

36 ibid., 186. 
great respect for their self-made fathers. ${ }^{37}$ What most distinguishes Ilbae is their sense of righteousness. Many say they prefer the corruption of the conservative government to the incompetence and hypocrisy of the leftist government. They also harbour resentment against women who demand equal treatment despite not having served in the military. These women include their girlfriends who make them pay for going on dates but offer little 'service' in return. To them, people with disabilities, foreign workers and mothers who get child support from the state are all parasites who feed off hard-working and tax-paying citizens. As such, these young people ignore structural inequalities and emphasise the values of selfreliance and individual responsibility. Within this framework, they view the birth of children into well-to-do families, for instance, as part of their personal 'ability'.

By virtue of some 20,000 people, who gather on its website every hour to curse, act in a rowdy manner, and vent their anger by calling each other losers, Ilbae has become South Korea's most powerful online community. Growing up in the aftershock of the IMF crisis, most Ilbae members have experienced cutthroat competition to get into college. As consumers of private after-school education since youth, many have internalised the 'winner-take-all' mentality of neoliberalism. Without any alternative role models, few have had a chance to cultivate a sense of belonging. To them, everything is 'private' and a 'matter of fact'. Despising anyone who talks about 'truth' without supporting 'facts', they dismiss kkon-dae (derogatory term for older people who always try to teach) who, in their minds, merely preach without providing any evidence. 'What is your real motive in bringing up the issue of compensation?' they ask the sympathetic and warm-hearted citizens who support the grieving families. Is it any surprise that people should be unable to care for others who are suffering when they have not received such care themselves? From a student, I heard of one 30-year-old woman, who, passing by the protest site of the surviving families, started screaming at them to stop 'nagging' the government. Having not received love and support themselves during their youth, they are unable to understand the suffering of others.

37 Kim Hak-june, 'Int'ŏnet kŏmyunit'i 'ilbejŏjangso-esŏ nat'ananŭn hyŏmo wa yŏlkwang ŭi kamchŏngtonghak' [The Emotional Dynamics of Hatred and Wildness in Internet Community's 'Ilbae Storage Site'], Master's thesis, Seoul National University, Sociology, 2014. Chun Gwan-yool, 'Iche kukka ap'e tangdanghi sŏn "ilpe ŭi ch'ŏngnyŏndŭl"' ['Ilbae Youth' Who Stand Proudly Before the Nation], Sisa-in, Issue 367 (29 September 2014). 
Considering themselves to be smarter and more sophisticated than gullible citizens who support the grieving families, these radicalised youths spend their days engaging in satirical discourse. Claiming 'You are an idiot, I'm an idiot', they refuse to take anything seriously. How are we to understand these radicalised youths who, after 30 bloody years of democracy protests, have emerged as cynical narcissists and conservative egoists, who dismiss the past decade of democratic politics as 'the lost decade'? According to sociologist Kim Hong-jung, the reason that these youths have emerged as cynical narcissists is because they have internalised the imperative to survive at all costs. ${ }^{38}$ Having adopted survivalism as their modus operandi, many youths not only fail to empathise with the pain of society's losers but also heap scorn and hatred upon them. In a slightly different context, philosopher Renata Saleci argues that when life becomes a brutal war for survival, the young generation, in particular, experiences a form of 'neurotic anxiety'. ${ }^{39}$ Just like post-traumatic stress disorder experienced by soldiers returning from battle, this neurotic anxiety can be seen as the result of a combination of factors. In evaluating the relationship between survivalism and conservatism, we may view it as the result of youth adapting themselves to a reality in which they feel social change is impossible.

Also undeniable is how effectively the conservative government has managed to manipulate both law and media within this gloomy environment to further their agenda. In aligning itself more strongly with the market, the Korean state seems to believe that it no longer needs to pay any attention to its more enlightened citizens. Instead, it can rely on money and power to pursue its political agenda. State manipulation of the media has become more sophisticated under the conservative regime of President Lee Myung-bak (known as the 'Economy President' because of his background as the former CEO of Hyundai Construction) and President Park Geun-hye, the daughter of Park Chung-hee, the military dictator responsible for the nation's economic development in the 1960s and 1970s. Under these two administrations, government control of political demonstrations has strengthened to the point that it is becoming

38 According to Kim, 'survivalism' is a collective psychology formed by people to respond effectively to the various problems created by the conditions of late modernity. Kim Hong-jung, 'Survival, Survival Ethics, and the Youth Generation', Hangook Sahoe-hak 49, Issue 1 (2015), 179-81.

39 Here, 'realistic anxiety' refers to a known danger while 'neurotic anxiety' refers to an unknown one. Renata Seleci, Puran [On Anxiety], trans. Bak Gwang-ho (Paju: Humanitas, 2015), 48-9. 
impossible to participate in them. ${ }^{40}$ With political parties needing only 30 per cent of the popular vote to win an election (because of low voter turnout), the right-wing party has focused on 'economic recovery' and 'threat of North Korean invasion' while the left-wing party has focused on the corruption and immorality of the right. Together, these two political stances mean that real issues affecting the country remain unaddressed. Within a political environment in which many citizens are becoming increasingly cynical, I fear the growth of a movement similar to Nazism in Germany during the early part of the 20th century. The likelihood of such movement emerging is very high when the 'industrial generation'who did not have the time or the leisure to cultivate a humanitarian consciousness-meets the 'neoliberal generation'-who are struggling to survive within the cruel and competitive society - under the umbrella of state power. As for the Sewol Ferry Disaster, after the government's successful recruitment of young foot-soldiers from the ranks of the calculating consumer generation, there appears to be no solution in sight. It is precisely because of this mounting sense of crisis that I highlight the issues of a 'weak state' and 'capitalism that has run out of steam', as well as of the politics of survival that must cultivate global citizens.

\section{People, Citizen, Refugee and the Politics of Survival}

On 16 April 2014, many citizens of South Korea became mesmerised by the scenes of a ferry sinking. Images of text messages and video footage - sent by the students to their parents and friends hours and even minutes before their death-kept the country glued to television sets and smartphones. What made this disaster particularly notable was the participation of the whole nation during its unfolding. Via its mediated representations, people participated in 'real' time, both in the unfolding events on the ferry and the ensuing rescue efforts. In the process, they became simultaneous 'witnesses' and 'survivors' of this disaster. With the sinking of the Sewol ferry, people have witnessed a chain reaction of crises in South Korean society.

40 On 29 September, the National Police Agency declared that a person would be arrested right away should they cross the police line. They also stated that they were pursuing legal amendments to double the penalty to a 'minimum of 6 months of imprisonment and a fine of $\$ 500(500,000$ won) and below'. Kim Seung-hwan, 'P'olrisŭ lainman nŏmŏdo kŏmgŏ... kyŏngch'al, chiphoe siwimunhwa okchoena' [Arrest for Even Crossing the Police Line ... Police Stranglehold of Rally and Protest Culture], Hankook Ilbo, 30 September 2015. 
It was during this period of growing intolerance that I became aware of the Syrian refugee crisis. On 2 September 2015, the world was gripped by the photo of a three-year-old child whose drowned body had washed up on the shores of the Mediterranean Sea in a resort town. Wearing a red T-shirt and navy blue shorts, face down in the sand, he was later identified as Aylan Kurdi, a child of a Syrian family who had been fleeing the country's five-year civil war for Europe. ${ }^{41}$ In the past five years, the Syrian refugee crisis has resulted in over 240,000 deaths, 4,013,000 refugees, and 7,600,000 displaced persons within its borders-representing the biggest displacement of people since the two world wars. ${ }^{42}$ Following the drowning of more than 2,000 boat people in the Mediterranean Sea in 2014, another 800 people drowned in April 2015 in the Libyan Sea. More than all these deaths, however, this one photo of a drowned child, which circulated widely over the internet with the hashtag 'Flotsam of humanity', struck at the hearts of people around the world.

When 20,000 Syrian refugees arrived in northern European cities such as Vienna and Munich, residents greeted them with hugs, gifts and welcoming applause. In Iceland, in an online discussion started by a group critical of the government's policy to accept only 50 refugees, 10,000 people volunteered to find housing for the refugees. ${ }^{43}$ A photo of a Syrian father selling ballpoint pens on the street while he cradled his sleeping daughter in his arms circulated on social media networks, and raised $\$ 140,000$ to help him. Liberalisation of refugee policies followed within some European nations. Buoyed by the outpouring of humanitarianism among her people, Germany's Prime Minister Angela Merkel, who had been so firm and tough about the recent Greek financial crisis, announced the country's acceptance of all Syrian refugee applicants. Relenting on his earlier anti-immigration stance, Denmark's Prime Minister Lars Lokke Rasmussen also announced the acceptance of 1,000 refugees. Watching

41 Cho Il-joon, 'P'atae Milryŏon 3sal Siria nanmin aiŭi chukŏm ... Chŏnsekye "Kongpun"' [The Corpse of a 3-year-old Syrian Refugee Child Swept up to the Beach by Waves ... world 'outrage'], Hankyoreh Newspaper, 3 September 2015.

42 Yul Lee, 'Five Years of Syria's Civil War ... 240,000 Deaths and 4 Million Refugees', Yonhap News, 7 August 2015.

43 Seo-young Ha, 'Refugee-Refusing European Governments, Citizens who Invite Refugees to Their Home', Joongang Daily, 3 September 2015. 
the European Commission's move 'to avoid a humanitarian tragedy' ${ }^{4}$ amid an outpouring of compassion, Korean media pundits exclaimed, 'This is the miracle that Aylan has bestowed upon humanity'. ${ }^{45}$

In collectively experiencing this tragic moment between life and death, human beings feel a sense of compassion that, previously deeply buried within their hearts, springs forth. While Korean Buddhist monk Tobŏp, during the Sewol Ferry Disaster, called this sense of spiritual awakening the 'heart of heaven' or 'sacred heart (körukhan maŭm)', lawyer Kim Tak-su declared it to be 'the first mind (chöt maŭm)'. In Durkheimian terms, we might view it as the emergence of a 'collective consciousness' when grieving and fearful people gather together and transcend their individual fear and suspicion anger to a higher order-the 'sacred'. Grieving the deaths of children both during the Syrian refugee crisis and Sewol Ferry Disaster, they are engaging in efforts both large and small to make sure such tragedies do not occur again-whether that means showing up at the train station laden with flowers to welcome the Syrian refugees or signing a petition to demand the proper investigation of the Sewol Ferry Disaster. Here I am asking how long humanitarian impulses or compassion that rise out of witnessing tragedies could last. There is talk about 'compassion fatigue'; people feel fatigue because they cannot find proper 'exit' for the confrontation with the state power. Moreover, people are getting busier as disastrous incidents and crises occur more frequently.

In this essay, I tried to describe a movement of compassionate and hospitable citizens and one of fearful and hate-mongering ones. These two contrasting movements and groups of citizens coexist as if they were two nations within one nation-state. Similarly, in the case of the Syrian refugee crisis, next to the outpouring of humanitarian compassion were scenes of open hostility directed against the refugees. On 8 September 2015, people around the world were shocked by the video of a female Hungarian journalist tripping a Syrian father, who was running away from the Hungarian police with a child in his arms, and then kicking a child refugee. ${ }^{46}$ They also became incensed when they watched a video

44 Duncan Robinson, Alex Barker, and James Politi, 'Greece Under Pressure to Set Up Facilities for 50,000 Refugees', Financial Times, 26 October 2015.

45 Song Young-in, 'Aillani Pakkun Sesang ... Tokilsŏ Nanmin Hwanyŏngmulkyŏl' [The World that Aylan has Changed ... The Wave of Welcome for Refugees in Germany], Yonhap News, 7 September 2015.

46 'Hungarian Camera Woman for Fascist Channel Caught on Camera Attacking Immigrants', YouTube video, 0:22, posted by 'Chewing tinfoil', 9 September 2015. www.youtube.com/watch?v=i Tasfpovhe4\&feature=youtu.be. 
of a young mayor in Àsotthalom, Hungary, ordering refugees to stay out of his town, while striking the pose reminiscent of a neo-Nazi thug or gun-toting cowboy. ${ }^{47}$ Where is this open animosity coming from? And what will happen to the growing sense of antipathy brewing in northern European countries? How long can the 'heart of heaven' that sprang forth from watching the pain of others last? Can I be hopeful, believing that uncovering the miseries and disasters will open a platform of collective learning of 'social catharsis' that can open new paths of survival for humankind?

After the Sewol Ferry Disaster, many academics have called for more public-minded 'citizens'. Sociologist Song Ho-gun, for instance, argues that much of Korean society's misery can be traced to its lack of public virtue. ${ }^{48}$ Noting that economic growth has far outpaced the development of sociopolitical virtues, he urges South Korean people to respect one another and serve the public as a community of self-governing people. I agree with his argument but feel the prescription is too simplistic. Having transformed itself from a strictly ruled colony to a leading economic power in a matter of 60 years, South Korea is pointed to as a model state for its successful 'take off. In the maelstrom of global capitalism, however, the people caught up in this compressed rush and ruled by an unforgiving developmental state had to compromise and sacrifice many things. As novelist Park Min-gyu explains above, with the 'ferry of South Korea' having started sailing in an unbalanced state, it cannot help but grow more tilted as it continues to sail. The obsession with catching up with so-called 'advanced nations' has spawned a nationalism and statism that tries to unify the population into one powerful nation. This mass hatred appearing in later developing nations such as present-day Korea and Hungary is a product of this crippling modernisation. I have closely followed the growing phenomenon of youths in such countries, who are sympathetic to this brand of insular nationalism. Their anger and frustration has surfaced because, although they may have joined the middle class in their own countries, the dreams they had of enjoying the kind of lives of comfort enjoyed by middle-class nuclear families in earlier developed nations have been dashed. Also, in countries where you must face dying alone without anyone to help you, those demanding help from

47 Cho Seung-hyun, "Nanmin hyŏppaksŏng” yŏngsang ollin hŏnggari sijang "uri tosiro omyŏn t'uok"' ['Threatening Refugees' The Video of Hungarian Mayor: Imprisonment if You Come to Our Town], Hankyoreh Newspaper, 19 September 2015.

48 Song Ho-gun, Nanŭn simininga sahoehakcha Songhokŭn, simin ŭi kirŭl mutta [Am I a citizen? Sociologist Song Ho-gun. asking about the path to citizenship] (Munhak Dong-ne, 2015). 
the state or others themselves must understand the level of anger that must pervade such a society, and its blowback effects, like the woman who angrily yelled at the families of the Sewol victims for 'nagging' the government. Because such people, as citizens, have not had the experience of receiving 'gifts' from the state or acts of 'caring', they themselves don't know how to give of themselves or care for others. Instead, they came to think that the proper way to live one's life is to exist each for oneself, living off one's own efforts alone. For these people, the Korean phrase first popularised during the hard times of the 1960s, 'Let's all prosper [live well] together', just seems like hypocrisy.

'Creating the public' involves building trust and cooperation among individual citizens. Compared with northern Europe, when one comes face-to-face with such expressions of naked hatred as in South Korea or Hungary, it is difficult to 'create a public'. In recent years, a growing number of politicians have capitalised on people's anxiety and hostility to seize state power. Such politicians want to separate the public into opposing groups in order to produce mass anger. They pay no heed to methods for constructively gaining and holding on to state power. They tend to emphasise 'economic growth' or 'economic recovery', while spending tremendous amounts to buy new weapons. They also ignore citizens' objections to continue supporting indefensible technologies such as nuclear power plants, fracking, and long-distance oil pipelines. Even as they make international agreements to forestall climate change, they make no efforts to ensure that the measures required by those agreements are carried out.

This kind of activity is not only occurring in the later developed countries. During his 2016 election campaign, US President Donald Trump emphasised a politics that pits group against group, stirring up hatred and hostility. Employing hateful speech as his weapon, he has succeeded in generating a sensational sideshow that attracts disaffected American voters. Trump has called Mexicans 'rapists', referred to women as 'bimbos' and 'fat pigs', and promised to shut down mosques, keep a database of Muslims, and round up the children of 'illegal' immigrants. Stephen Miles of Avaaz has commented that 'Trump isn't the only politician on the global stage exploiting political alienation and fear to sow hate, but he's the only one who is doing it with $\$ 2$ billion worth of media attention'. Miles said he hopes to 'use Trump's media magnetism to our advantage and 
trigger a massive story about the world rejecting this hate-mongering. ${ }^{49}$ My cousin, who sent me this anti-Trump initiative, commented that 'I thought Trump's campaign was a joke and a publicity stunt and can't believe he has gotten this far'.

What about the first 'advanced nations' in Europe? How are they faring compared to the later developed countries? With the continued stagnation of their economies, there is a growing trend towards political conservatism and radicalisation of patriotic youth in advanced nations as well. As societies become more conservative, the welcoming gestures of citizens in northern Europe towards Syrian refugees cannot but seem more precious. Their gestures of warmth and empathy are not enough to solve the situation of Syrian refugees. Are they the 'kind but incompetent' citizens that some Korean youth mock as the 'obnoxious left' or citizens who have had their consciousness 'raised'? I admire people in European social democracies in their long-term effort to overcome sheer capitalistic greed after the two world wars, but I also know that it would not be easy for them to move out of their 'comfort zone'.

Within the current world order, which is characterised by unending series of disasters, catastrophes and hostility, no place on the globe is safe. For future generations, we leave behind a devastated ecosystem, the terror of new viruses, economies on the brink of collapse, the danger of nuclear arms and weapons plants, heightened class conflicts, a widening divide between the rich and poor, high youth unemployment, low fertility, ageing societies without systems for providing adequate elder care, and the fears and anxieties that follow the collapse of national economies. Within this context, I propose that we replace the binary of 'sónjin-guk vs hujin-guk', the 'advanced/developed nation vs undeveloped/developing nation', deeply embedded within the modern mindset, with the notion of 'sonmang-guk vs humang-guk', the 'rapidly vs slowly collapsing/declining/burningout nation'. This may involve replacing the indices that measure Gross National Product with indices that reflect their potential destructiveness. Such indices should take into account the number of nuclear power plants

49 This following letter appears on Avaaz.org: 'Dear Mr. Trump, This is not what greatness looks like. The world rejects your fear, hate-mongering, and bigotry. We reject your support for torture, your calls for murdering civilians, and your general encouragement of violence. We reject your denigration of women, Muslims, Mexicans, and millions of others who don't look like you, talk like you, or pray to the same god as you. Facing your fear we choose compassion. Hearing your despair we choose hope. Seeing your ignorance we choose understanding. As citizens of the world, we stand united against your brand of division. Sincerely.' (The petition already has approximately 5,112,000 signatures as of March 2017) avaaz.org/en/deartrump_rb_loc/?acDWXcb. 
in a nation, the degree of disconnectedness and atomisation among its members, or its potential for dealing with the innumerable contingencies. In this context, the concept of 'refugee' in survival politics proves far more useful than the concepts of 'national subject' or 'citizen' in a 'politics of progress'. During the Sewol Ferry Disaster, people in South Korea who once believed in the myth of economic development begin to increasingly realise that the state is but 'a system of organised irresponsibility'. ${ }^{50}$ After overcoming their sense of astonishment and bewilderment when gazing upon the 'unpainted face' of the nation-state, they have begun the long journey of overcoming their abject situation. Already, I have encountered many who have embarked on this journey by embracing a refugee-like existence including self-exile or psychological refuge. They ask questions such as 'Will Japan or China accept us if we also become refugees?' 'Or will we die as boat people in the East Sea/Sea of Japan?' 'Is it better to leave this country before that happens? If so, where?' In the departure of these youth for a better life elsewhere, one can find a reason for Ulrich Beck's hope in the face of countless disasters and untold miseries that characterise risk society. According to Beck, the shock administered to humanity by massive disasters will also produce the 'conditions for cosmopolitanism', resulting in countless miracle-like events, including a new social consensus on the environment. His colleague Bruno Latour has also said, 'society has never been the equivalent of a nation-state' and 'society has always meant association and has never been limited to humans'. ${ }^{51}$ With the disappearance of one cosmos, Latour further suggests using the term cosmopolitics instead of cosmopolitan. ${ }^{52}$ Here, I want to suggest that young people engage in survival politics by becoming 'global refugees' to transform the present catastrophe into an emancipatory one.

In October 2015, I visited International People's College in Denmark, the sister school of Haja Production School, which I founded after the Asian financial crisis in Seoul. A boarding school with approximately 100 students from over 35 countries, the International People's College is an excellent global school that aims to foster 'global citizens'. While I was there, the principal and teachers were discussing how to cultivate compassion and competence as global citizens among the students. Based on my limited observation, the problem appeared to lie in their concept

50 Interview with Ulrich Beck, 'System of organized irresponsibility behind the Fukushima crisis', Asahi Shimbun, 8 July 2011, blog.sina.com.cn/s/blog_7ab41de50100tb1n.html.

51 Bruno Latour, 'Whose cosmos, which cosmopolitics?' Common Knowledge 10, no. 3 (2004): $450-51$.

52 ibid., 453. 
of citizenship. The courses at the school covered many important topics such as the historical roots of the violence of the Australian state against its Aboriginal population and issues surrounding the multinational corporations, such as Monsanto. Still, students seemed to have a hard time personalising these issues and accepting them as their own. While students from the humang-guk - the 'slowly collapsing/declining/burnout nations' - appeared somewhat tired of these dystopian stories, for the students from sŏnmang-guk - the 'rapidly collapsing/declining/burningout nations'- the challenges were too real to face.

What is clear here is that these youngsters are going to have to come to terms with the fact that these local disasters and catastrophes are globally connected. From this perspective, I find the term 'global refugee' much more useful than 'global citizen'. Whether one has been physically displaced or not, the personal realisation that one is being displaced from one's country of citizenship is likely to be a good start of learning. In coming to this realisation and cultivating one's sense of being a refugee, these displaced citizens may do well to heed the words of one native woman from the Chiapas region in Mexico:

If you have come here to help me, you are wasting your time. But if you have come because your liberation is bound up with mine, then let us work together. ${ }^{53}$

\section{Acknowledgements}

I presented the draft of this essay at the symposium, 'Reflections of Humanities on April 16th Sewol Disaster and Disaster Studies', held at the Humanities Research Center at Seoul National University on 31 October 2104. I am grateful to Hirokazu Miyazaki at Cornell University, Takashi Fujitani, Jennifer Chun and Judy Han at the University of Toronto, Tessa Morris-Suzuki at The Australian National University, and Dongjun Shin at Cambridge University for providing me further opportunities to think over the Sewol Ferry Disaster. I am particularly grateful to Song-Pae Cho, Jeffrey Stark and Eun Jeong Soh for translating and making this essay filled with abrupt generalisations and emotional nuances into a readable English essay.

53 School for Chiapas, 'Women's Empowerment', www.schoolsforchiapas.org/advances/womensempowerment/. 
This text is taken from New Worlds from Below: Informal life politics and grassroots action in twenty-first-century Northeast Asia, edited by Tessa Morris-Suzuki and Eun Jeong Soh, published 2017 by ANU Press, The Australian National University, Canberra, Australia. 